Human and Animal Health

Vol.61: e18160623, 2018

http://dx.doi.org/10.190/1678-4324-2018160623

ISSN 1678-4324 Online Edition
BRAZILIAN ARCHIVES OF BIOLOGY AND TECHNOLOGY

\title{
Evaluation of Anticancer Activity of Extracted Flavonoids from Morus Alba Leaves and its interaction with DNA
}

\author{
Soudabeh Fallah ${ }^{1 *}$, Zahra Hajihassan ${ }^{2}$, Nasrin Zarkar ${ }^{3}$, Azra Rabbani- Chadegani ${ }^{3}$, Javad \\ Mohammadnejad ${ }^{2}$, Milad Hajimirzamohammad ${ }^{1}$. \\ ${ }_{1}$ Biochemistry Department, Iran University of Medical Sciences, Tehran, Iran; ${ }^{2}$ Life Science Engineering \\ Department, Faculty of New Sciences and Technologies, University of Tehran, Tehran, Iran; ${ }^{3}$ Biochemistry \\ Department, Institute of Biochemistry and Biophysics, University of Tehran, Tehran, Iran
}

\begin{abstract}
Morous Alba, known as white mulberry contains many oxidative flavonoids, widely used in the treatment of many diseases like hyperglycemia, inflammation, fever and cancer. In the present study we investigated the interaction of extracted flavonoids from Iranian Morus Alba leaves with DNA as a main target for anticancer drugs. Various spectroscopic techniques (UV/Vis, CD and Fluorescence Spectroscopy) were used to detect the interaction. In vivo studies also were done to confirm the effectiveness of the extracted flavonoids. The spectroscopic results showed that the extracted flavonoids bind to DNA especially to the sugar-phosphate backbone and making DNA conformational changes upon this binding. Experiments on the cancerous mice with solid tumors indicated that the treatment of mice with these extracted flavonoids increased significantly the life span but they did not have any effects on the tumor size reduction. These data suggest that Morus Alba flavonoids may use as an effective natural anticancer drug in the near future.
\end{abstract}

Key words: Flavonoids; anticancer activity; DNA interaction; Morus Alba

\footnotetext{
Authors for correspondence: fallah.s@iums.ac.ir, hajihasan@ut.ac.ir
} 


\section{INTRODUCTION}

In last years, research on medicinal plants has been increased. Mulberry plant is one of the traditional herbs used as medicine in China and India. Morus Alba, known as white mulberry is reported to contain many anti oxidative flavonoid compounds. It has also hypoglycemic, hypolipidemic and antioxidant effects. Its leaves show valuable effects because of the presence of steroids, flavonoids, amino acids, vitamins and other trace elements. The leaves have been used for years in china to

treat hyperglycemia, inflammation, cough, hypertension, cancer and fever ${ }^{1-3}$. The data indicate that flavonoids that are present in the leaves possess anti-inflammatory, antioxidant, antiallergic, hepatoprotective, antiviral, antimicrobial and anticancer activities $4-6$.

Similarly, anticancer drugs like anthracyclines and their derivatives have also phenolic rings similar to flavonoids. These drugs enter the cell nucleus and bind chromosomal DNA. Intercalation between DNA base pairs leading to inhibition of DNA and RNA synthesis was the first mechanism described for cytotoxicity of

anthracyclines 7,8 . As Morus Alba leaves contain flavonoids that are resemble structurally to anthracyclines, chromosomal DNA may be the target of extracted flavonoids too. Therefore, in this research interaction of flavonoids extracted from Iranian Morus Alba (FIMA) leaves with DNA was studied in order to understand the exact mechanism of Morus Alba flavonoids action. The results provide evidence that FIMA binds to backbone of chromosomal DNA and making DNA conformational changes. Also in vivo studies showed that FIMA treatment increases the life span of cancerous mice.

\section{MATERIALS AND METHODS}

\section{Extraction and purification of flavonoids from mulberry leaves}

A modified method of Chen was used for extraction and determination of flavonoids 9

. Dried leaves from Iranian Morus alba were used for extraction of total flavonoids. Powdered material was extracted twice with $70 \%$ ethanol solution at $90^{\circ} \mathrm{C}$ for $2 \mathrm{~h}$. After filtration and centrifugation (3000 rpm, $15 \mathrm{~min})$, the solvent was evaporated and the aqueous extract was condensed under reduced pressure. $1 \mathrm{ml}$ of the solution containing flavonoids was mixed with $0.7 \mathrm{ml}$ of $5 \%$ (w/w) NaNO2, $10 \mathrm{ml}$ of $30 \%$ $(\mathrm{v} / \mathrm{v})$ ethanol and $0.7 \mathrm{ml}$ of $10 \% \mathrm{AlCl} 3(\mathrm{w} / \mathrm{w})$ and the mixture was then stirred for 6 min. Then, $5 \mathrm{ml}$ of $1 \mathrm{~mol} / \mathrm{l} \mathrm{NaOH}$ was added. Finally, the NKA-9 macroporous resins were chosen for purification of the separated flavonoids from the crude extract. The purified flavonoids were diluted to $1.5 \mathrm{mg} / \mathrm{ml}$ and stored at $4^{\circ} \mathrm{C}$ before use.

\section{UV/Vis spectroscopy}

Calf thymus DNA $(50 \mu \mathrm{g} / \mathrm{ml})$ was dissolved in $10 \mathrm{mM}$ Tris- $\mathrm{HCl}(\mathrm{pH}=7.4)$ and incubated with different concentrations of extracted flavonoids for 45 min at room temperature. Control samples containing equal volumes of calf thymus DNA in the same buffer were incubated along with the flavonoids treated samples under the same condition. The treated and control samples were then subjected to spectroscopic analysis using Shimadzo UV-160 spectrophotometer. The wavelengths of 210 and $260 \mathrm{~nm}$ were selected to detect the extracted flavonoids effect on DNA. Each experiment was repeated at least three times. 


\section{Fluorescence Spectroscopy}

The measurements were performed on Carry Eclipse fluorescence spectrophotometer. All samples were made in $10 \mathrm{mM}$ Tris $-\mathrm{HCl}(\mathrm{pH}=7.4)$ and quartz fluorescence cell of $1 \mathrm{~cm}$ path length was used in the experiment. The spectra were recorded between $350-400 \mathrm{~nm}$ after excitation at $370 \mathrm{~nm}$. Each experiment was repeated at least three times.

\section{Circular dichroism experiment}

Circular dichroism (CD) experiment was performed using CD spectrometer model 215 (Aviv instrument INC). The far-UV CD spectra of DNA in $10 \mathrm{mM}$ Tris- $\mathrm{HCl}$ $(\mathrm{pH}=7.4)$ and in the absence and presence of various concentrations of extracted flavonoids were recorded in the range of 220-300 $\mathrm{nm}$ with a spectral resolution of 1 $\mathrm{nm}$. The scan speed was $20 \mathrm{~nm} / \mathrm{min}$ and the response time was $0.33030 \mathrm{sec}$ with a band width of $1 \mathrm{~nm}$. Quartz cell with a path length of $10 \mathrm{~mm}$ was used and all measurements were carried out at $25^{\circ} \mathrm{C}$. Results are expressed as molar ellipticity expressed as [ $\theta]$, in $\operatorname{deg} \times \mathrm{cm}^{2} \times \mathrm{dmol}^{-1}$.

\section{In vivo studies}

A LL2 cell line (derived from transplantable murine Lewis lung carcinoma) was grown in RPMI-1640 medium supplemented with $10 \%$ heat inactivated fetal calf serum, $2 \mathrm{mM}$ glutamine, $100 \mu \mathrm{g} / \mathrm{ml}$ streptomycin and $100 \mathrm{IU} / \mathrm{ml}$ penicillin. Ten normal female BALB/c mice (inbred, 20-30 gr) that were 8-10 weeks old selected for tumor transplantation. The animals were received from the Pasteur Institute (Tehran, Iran) maintained under standard temperature $\left(22 \pm 0.5{ }^{\circ} \mathrm{C}\right)$ and light in conditions (12-h light/12-h darkness) with free access to food and water. All experiments were executed in accordance with the Guide for Care and Use of Laboratory Animals and were approved by the Institutional Ethics Committee - Iran University of Medical Sciences (IR.IUMS.REC 2015/12460).

The lung tumor xenograft was established by subcutaneous injection of two million LL2 cells (in PBS) in the right flank region of the mice. The therapeutic studies were performed when xenografts volume reached $50 \mathrm{~mm} 3$ in all mice. Then FIMA treatment was done in 5 cancerous mice and intravenous injection of $50 \mathrm{mg} / \mathrm{mL}$ of FIMA was done via the tail vein. 5 mice were used as controls and injected with phosphate buffer saline (PBS). Injection was repeated in every 3 days. The size of the tumors was measured in 3 dimensions every 3 days with an electronic slide caliper until the tumor volumes exceeded $1000 \mathrm{~mm}$ (9th day). Tumor volume was calculated as:

$$
\nu=\frac{4}{3} \pi \times r_{1} \times r_{2} \times r_{3},
$$

Where $r 1, r 2$, and $r 3$ are tumor radii in 3 dimensions, expressed in cubic millimeters 10.

\section{RESULTS AND DISCUSSION}

\section{FIMA binds to DNA backbone}

In recent years many studies have been done to determine the components of Morus Alba leaves; the focus was on the antioxidative and hypoglycemic effects 11,12 . In the present study an experiment was designed using calf thymus DNA incubated in the presence and absence of the various concentrations of FIMA. As is seen in figure 1, at low concentrations of FIMA (up to $30 \mu \mathrm{g} / \mathrm{ml}$ ) a slight decrease in the 
absorbance at $260 \mathrm{~nm}$ is observed but at higher FIMA values the absorbance is remained unchanged. But on the other hand, the absorbance at $210 \mathrm{~nm}$ is considerably decreased when FIMA concentrations is increased. As previous data indicate that absorbance changes of DNA spectrum at 210 and $260 \mathrm{~nm}$ upon drug binding is due to the binding of the drug to DNA backbone and DNA base pairs respectively ${ }^{13}$; so the results obtained here show that FIMA binds specially to the DNA backbone (sugar and phosphate) instead of binding to DNA base pairs. These findings are in contrast to the interaction of most anthracyclines like daunomycin with DNA showing that they bind chiefly to DNA base pairs instead of DNA

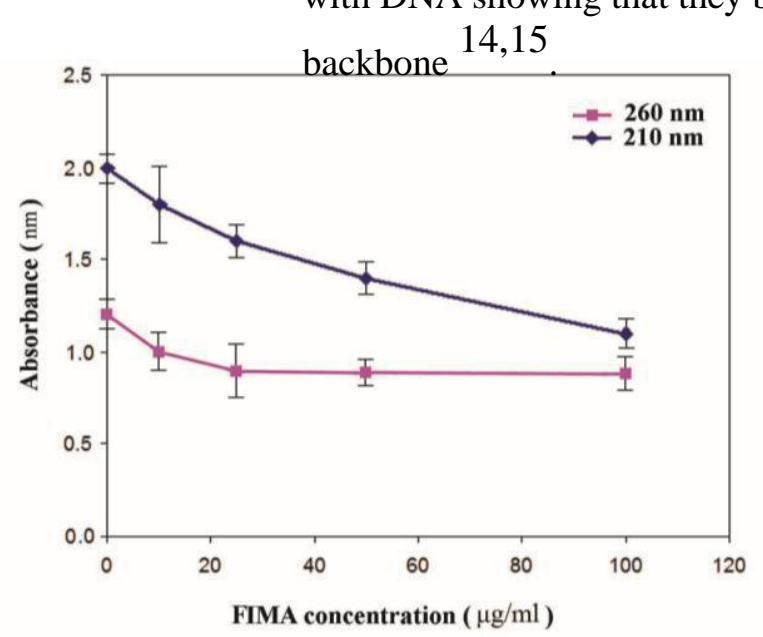

Figure 1: Absorbance changes of calf thymus DNA at 210 (diamond) and $260 \mathrm{~nm}$ (square) upon FIMA binding. The reaction was carried out in $10 \mathrm{mM}$ Tris- $\mathrm{HCl}(\mathrm{pH}=7.4)$ and incubation time was $45 \mathrm{~min}$. Results are average of 3 individual experiments.

\section{FIMA causes hypochromisity in the DNA fluorescence profile}

The florescence emission spectra obtained from the interaction of FIMA with calf thymus DNA is also shown in figure 2. DNA, in the absence of FIMA exhibit emission spectrum with a maximum intensity at $375 \mathrm{~nm}$. Addition of FIMA to the DNA solution reduces the fluorescence intensity of the DNA without any red shift in the emission maxima (Imax) as FIMA concentration is increased. The reduction in fluorescence emission of DNA is due to quenching of its functional groups. It is important to note that the fluorescence results presented here are very similar to those previously reported for daunomycin and idarubicin as anthracycline drugs. They also induced reduction of fluorescence emission intensity upon binding to

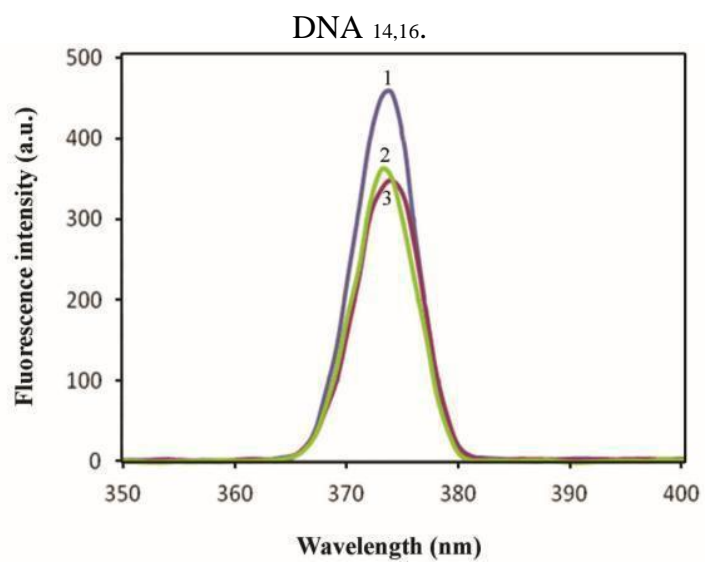

Figure 2: Fluorescence emission spectra of calf thymus DNA in the presence and absence of various concentrations of FIMA. All samples were prepared in $10 \mathrm{mM}$ Tris- $\mathrm{HCl}(\mathrm{pH}=7.4)$. Excitation was at $370 \mathrm{~nm}$. Spectra 1-3 are 0, 50 and $100 \mu \mathrm{g} / \mathrm{ml}$ of FIMA respectively. 


\section{FIMA causes DNA conformational changes}

To obtain further information about the binding of FIMA to DNA, we compared the CD spectrum of DNA in the presence and absence of FIMA. As shown in figure 3, DNA displays a CD spectrum with negative and positive extremes at 245 and 275 $\mathrm{nm}$ respectively. FIMA treatment caused a gradual decrease in the intensity of the peaks, which implies the conformational changes of DNA upon FIMA binding. These results are in agreement with CD reports for anthracycline drugs; they alter the

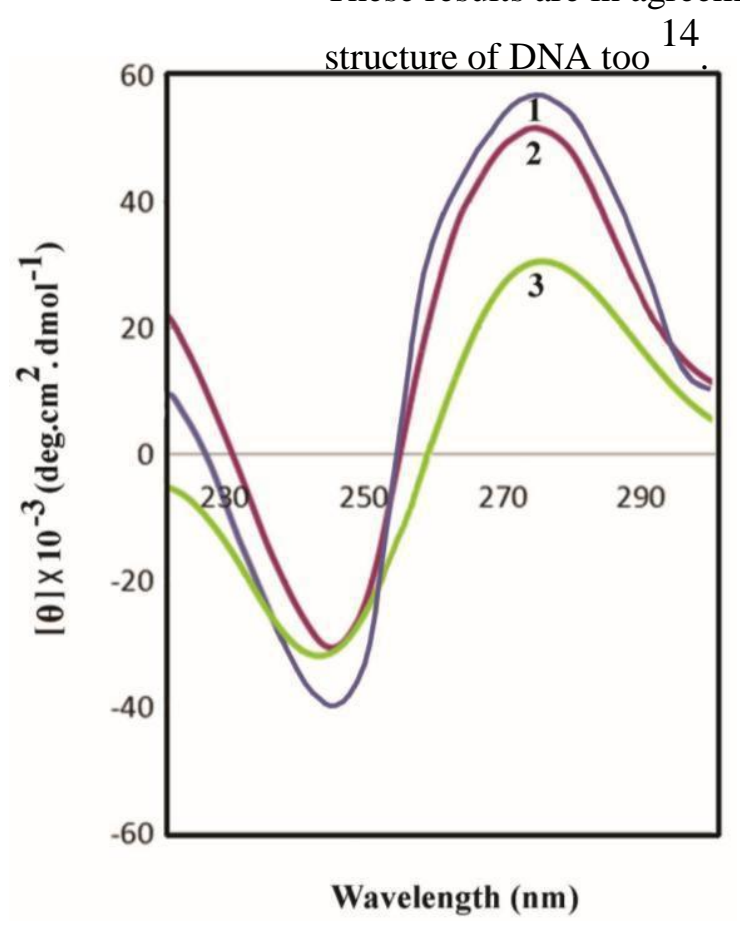

Figure 3: Far UV CD spectra of DNA in $10 \mathrm{mM}$ Tris- $\mathrm{HCl}(\mathrm{pH}=7.4)$ in the absence and presence of FIMA. 1-3 are 0, 50 and $100 \mu \mathrm{g} / \mathrm{ml}$ of FIMA respectively.

\section{FIMA treatment increases the life span of cancerous mice}

In this study, we measured the size of tumor in two groups (control and treated mice) until the tumor volumes exceeded $1000 \mathrm{~mm}$ as described in material and methods section. As it can be seen from figure 4, the size of tumor in two groups is increased, so in the ninth day, the tumor volume average in the control and in the treated group were $925 \mathrm{~mm}^{3}$ and $753 \mathrm{~mm}^{3}$ respectively. Of course the growth of tumors in the mice continued after ninth day. The data shows that FIMA treatment does not stop or slow down tumor growth because mean volume tumor in 2 groups did not show any meaningful differences; the calculated $p$ value was also greater than 0.05 .

Also the survival rate of mice was calculated and summarized in figure 5. As shown in the figure, the drug (FIMA) has significant impact on the survival rate of cancerous mice (the calculated $p$ value was less than 0.05 ) because the control mice that did not receive any FIMA could survive up to 9 days, but the treated mice could survive up to 26 days (three times more). Furthermore, treated mice have $100 \%$ viability up to 17 days but control group has this amount of viability up to 3 days. 


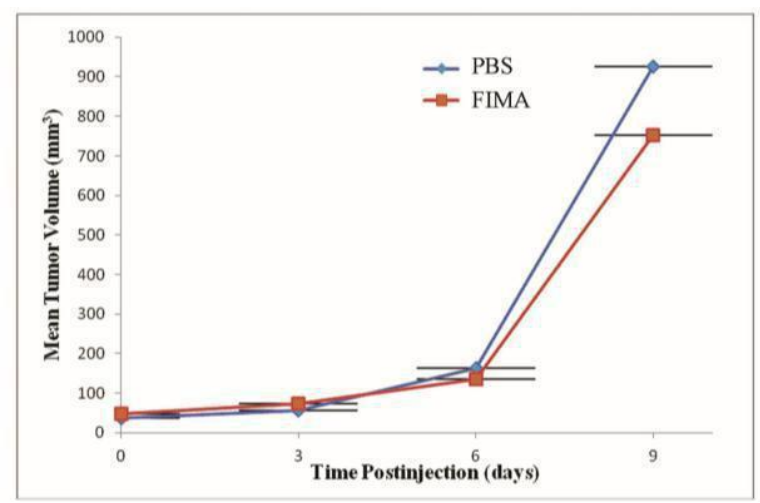

Figure 4: Comparison of the mean tumor volume in treatment and control groups. Each group consists of 5 mice.

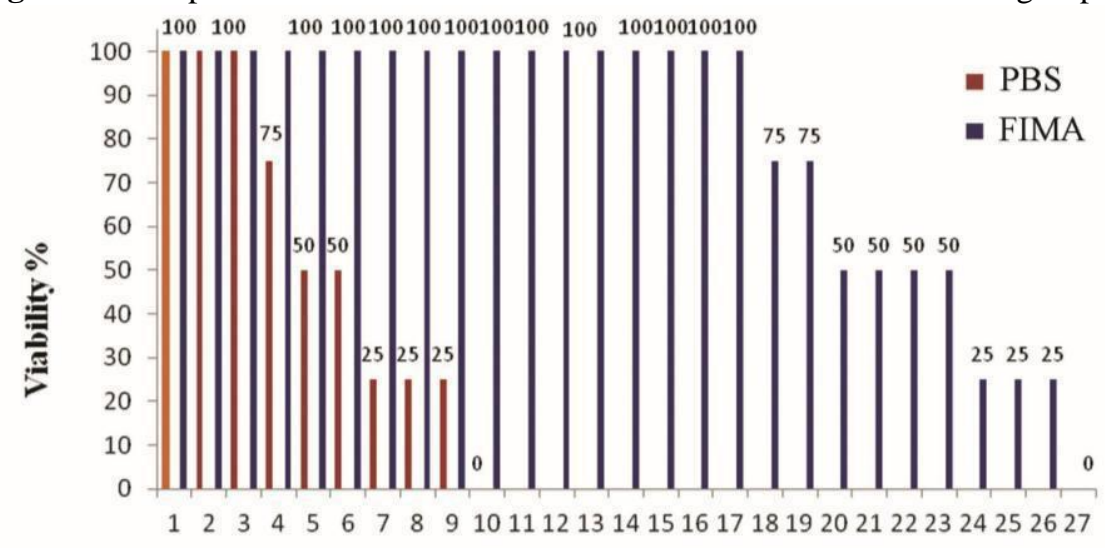

Time Postinjection (day)

Figure 5: Survival rate of control and treated mice.

\section{CONCLUSIONS}

The data presented here suggest that FIMA binds to DNA backbone as absorbance reduction at $210 \mathrm{~nm}$ shows. Also FIMA causes DNA conformational changes upon binding as fluorescence intensity reduction of the DNA and gradual decrease in the intensity of the DNA CD peaks show. Also treatment of cancerous mice with FIMA has a significant impact on the survival rate; despite it does not stop or slow down the tumor growth. It is suggested that further studies has to be done in order to understand the exact FIMA mechanism of action. Also FIMA can be used in combination with other anticancer drugs to increase the life span of patients in the near future.

\section{ABBREVIATIONS}

FIMA: flavonoids extracted from Iranian Morus Alba; CD: Circular dichroism

\section{COMPETING INTERESTS}

The authors declare that they have no competing interests. 
Anticancer Activity of Morus Alba Flavonoids

\section{ACKNOWLEDGMENTS}

The work was financially supported by the Iran University of Medical Sciences (grant no. 04.30.12460). The authors thank University of Tehran because of its permission to use the laboratories to do the research. The authors thank Seyed Jamal Ashrafi who helped in cell culture and in vivo studies.

\section{REFERENCES}

1. Devi B, Sharma N, Kumar D, Jeet K. Morus Alba linn: a phytopharmacological review. Int J Pharm Pharm Sci. 2013; 5: 4-18.

2. Singab AN, El-Beshbishy HA, Yonekawa M, Nomura T, Fukai T. Hypoglycemic effect of Egyptian Morus alba root bark extract: effect on diabetes and lipid peroxidation of streptozotocin-induced diabetic rats. J Ethnopharmacol. 2005; 100(3): 333-8.

3. Sohn HY, Son KH, Kwon CS, Kwon GS, Kang SS. Antimicrobial and cytotoxic activity of 18 prenylated flavonoids isolated from medicinal plants: Morus alba L., Morus mongolica Schneider, Broussnetia papyrifera (L.) Vent, Sophora flavescens Ait and Echinosophora koreensis Nakai. Phytomedicine. 2004; 11(7-8): 666-72.

4. Kim SY, Gao JJ, Lee WC, Ryu KS, Lee KR, Kim YC. Antioxidative flavonoids from the leaves of Morus alba. Arch Pharm Res. 1999; 22(1): 81-5.

5. de Oliveira AM, Mesquita Mda S, da Silva GC, de Oliveira Lima E, de Medeiros PL, Paiva PM, et al. Evaluation of Toxicity and Antimicrobial Activity of an Ethanolic Extract from Leaves of Morus alba L. (Moraceae). Evid Based Complement Alternat Med. 2015; 513978.

6. Dat NT, Binh PT, Quynh le TP, Van Minh C, Huong HT, Lee JJ. Cytotoxic prenylated flavonoids from Morus alba. Fitoterapia. 2010; 81(8):1224-7.

7. Hajihassan Z, Rabbani-Chadegani A. Studies on the binding affinity of anticancer drug mitoxantrone to chromatin, DNA and histone proteins. J Biomed Sci. 2009; 16: 31.

8. Rabbani A, Finn RM, Ausió J. The anthracycline antibiotics: antitumor drugs that alter chromatin structure. Bioessays. 2005; 27(1): 50-6.

9. Chen Y. Determination of total flavonoids in tartary buckwheat. Food Science. 1998; 13: 54-56.

10. Richtig E, Langmann G, Müllner K, Richtig G, Smolle J. Calculated tumour volume as a prognostic parameter for survival in choroidal melanomas. Eye. 2004; 18: 619-623.

11. Kim DS, Kang YM, Jin WY, Sung YY, Choi G, Kim HK. Antioxidant activities and polyphenol content of Morus alba leaf extracts collected from varying regions. Biomed Rep. 2014; 2(5): 675-680.

12. Sarikaphuti A, Nararatwanchai T, Hashiguchi T, Ito T, Thaworanunta S, Kikuchi K, et al. Preventive effects of Morus alba L. anthocyanins on diabetes in Zucker diabetic fatty rats. Exp Ther Med. 2013; 6(3): 689-695.

13. Sirajuddin M, Ali S, Badshah A. Drug-DNA interactions and their study by UV-Visible, fluorescence spectroscopies and cyclic voltametry. J Photochem Photobiol B. 2013; 124:1-19.

14. Rabbani-Chadegani A, Keyvani-Ghamsari S, Zarkar N. Spectroscopic studies of dactinomycin and vinorelbine binding to deoxyribonucleic acid and chromatin. Spectrochim Acta A Mol Biomol Spectrosc. 2011; 84(1): 62-7.

15. Rauf S, Gooding JJ, Akhtar K, Ghauri MA, Rahman M, Anwar MA, et al. Electrochemical approach of anticancer drugs--DNA interaction. J Pharm Biomed Anal. 2005; 37(2): 205-17.

16. Ozluer C, Kara HE. In vitro DNA binding studies of anticancer drug idarubicin using spectroscopic techniques. J Photochem Photobiol B. 2014; 138: 36-42. 